Table 1. Analyses of heavy mineral concentrates from stream sediments in the Atâ area

\begin{tabular}{|c|c|c|c|c|c|c|}
\hline & Scheelite/1 & W ppm & Au ppb & Ba ppm & Sieves & Vol \\
\hline $353001^{\bullet}$ & 0 & 16 & $<17$ & 450 & 3 & 0.2 \\
\hline 353002 & 10 & 65 & $<5$ & 320 & 3 & 0.5 \\
\hline $353003^{\circ}$ & 6 & $<7$ & $<5$ & 270 & 3 & 0.6 \\
\hline 353004 & 3 & 15 & $<5$ & 250 & 3 & 0.3 \\
\hline 353005 & 0 & $<6$ & $<5$ & 370 & 3 & 0.25 \\
\hline 353006 & 2 & $<5$ & $<5$ & 420 & 3 & 0.45 \\
\hline 353007 & 3 & $<2$ & $<5$ & 460 & 3 & 0.3 \\
\hline 353008 & 21 & $<9$ & 37 & 280 & 3 & 0.35 \\
\hline 353009 & 0 & $<7$ & $<5$ & $<100$ & 3 & 0.56 \\
\hline 353010 & 0 & $<6$ & $<5$ & 650 & 3 & 0.5 \\
\hline $353011^{\circ}$ & 30 & 120 & $<5$ & 4300 & 3 & 0.51 \\
\hline $353012^{*}$ & 64 & 81 & 16 & 240 & 3 & 0.26 \\
\hline 353013 & 1 & 7 & $<5$ & 260 & 60 & 5.21 \\
\hline 353014 & 0 & 13 & $<13$ & $<100$ & 4 & 0.2 \\
\hline 353015 & 0 & $<5$ & $<5$ & 500 & 4 & 0.42 \\
\hline 353016 & 0 & $<5$ & $<5$ & 430 & 4 & 0.09 \\
\hline 353017 & 0 & 24 & $<17$ & $<100$ & 4 & 0.35 \\
\hline 353018 & 0 & $<4$ & $<5$ & 730 & 3 & 0.1 \\
\hline 353019 & 0 & $<6$ & 19 & 320 & 3 & 0.2 \\
\hline 353020 & 0 & $<8$ & 15 & 1400 & 6 & 0.5 \\
\hline 353021 & 1 & $<5$ & $<5$ & 380 & 20 & 1.45 \\
\hline 353022 & 0 & $<6$ & $<5$ & $<100$ & 2 & 1.51 \\
\hline 353024 & & $<9$ & $<5$ & 440 & 3 & 0.2 \\
\hline $353025^{\circ}$ & 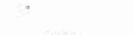 & 44 & $<5$ & 260 & 3 & 0.2 \\
\hline $353026^{*}$ & 32 & 93 & 32 & 290 & 6 & 0.6 \\
\hline $353027^{\circ}$ & 6 & 10 & $<5$ & 330 & 6 & 0.55 \\
\hline $353028^{*}$ & 0 & 7 & $<5$ & 440 & 3 & 0.35 \\
\hline
\end{tabular}

* Samples collected in amphibolite facies.

pancy between 21 grains of scheelite and less than 9 ppm tungsten in sample 353008 .

The gold contents in the heavy mineral concentrates are mostly too small to be detected. However, a few samples do contain interesting amounts of gold, and there is apparently some correlation between the gold content and the number of scheelite grains in the heavy mineral concentrates.

It should be noted that some stream sediments were collected in streams draining amphibolite facies metamorphosed supracrustal rocks; 353001 , 353003; 353011353012; 353025-353028.

\section{Conclusion}

This limited stream-sediment programme indicates that economically interesting tungsten occurrences may be found in the supracrustals of the Atâ area. Most of the scheelite apparently occurs in the supracrustal rocks which have undergone amphibolite facies metamorphism.

From this work and from the abundance of scheelite previously discovered in the supracrustal rocks further south (Appel, 1988) it is concluded that scheelite is probably more common in Precambrian supracrustal sequences than hitherto realised.

\section{References}

Appel, P. W. U. 1988: Heavy mineral concentrates from stream sediments collected in the Nuuk area, West Greenland during the period 1982-1987. Unpubl. intern. GGU rep.

Knudsen, C., Appel, P. W. U., Hageskov, B. \& Skjernaa, L. 1988: Geological reconnaissance in the Precambrian basement of the Atâ area, central West Greenland. Rapp. Grønlands geol. Unders. 140.

\title{
Reconnaissance aeromagnetic survey east of Disko Bugt, central West Greenland
}

\author{
Leif Thorning
}

The Geological Survey of Greenland plans a major aeromagnetic survey in the Disko Bugt region over the coming years. It has already been started with some introductory work in 1986 and 1987 (Knudsen et al., 1988). In this context, closed-file geophysical data were reviewed at GGU, and it soon became clear that good quality regional aeromagnetic data were lacking from the area and that the geological investigations would benefit from such data. Funds were not available for a systematic survey over the entire area, but in April 1987 a situation arose in which at least part of the area could be surveyed.

Due to the change of plans for the aeromagnetic surveying of the GICAS project, described by Thorning et al. (1988), it was possible to include one survey flight east of Disko Bugt. The measurements were made from the National Aeronautical Establishment aircraft (CFNRC), which is a well equipped Convair-580 with very good navigational capabilities and a 3-axis magnetic gradiometer. 


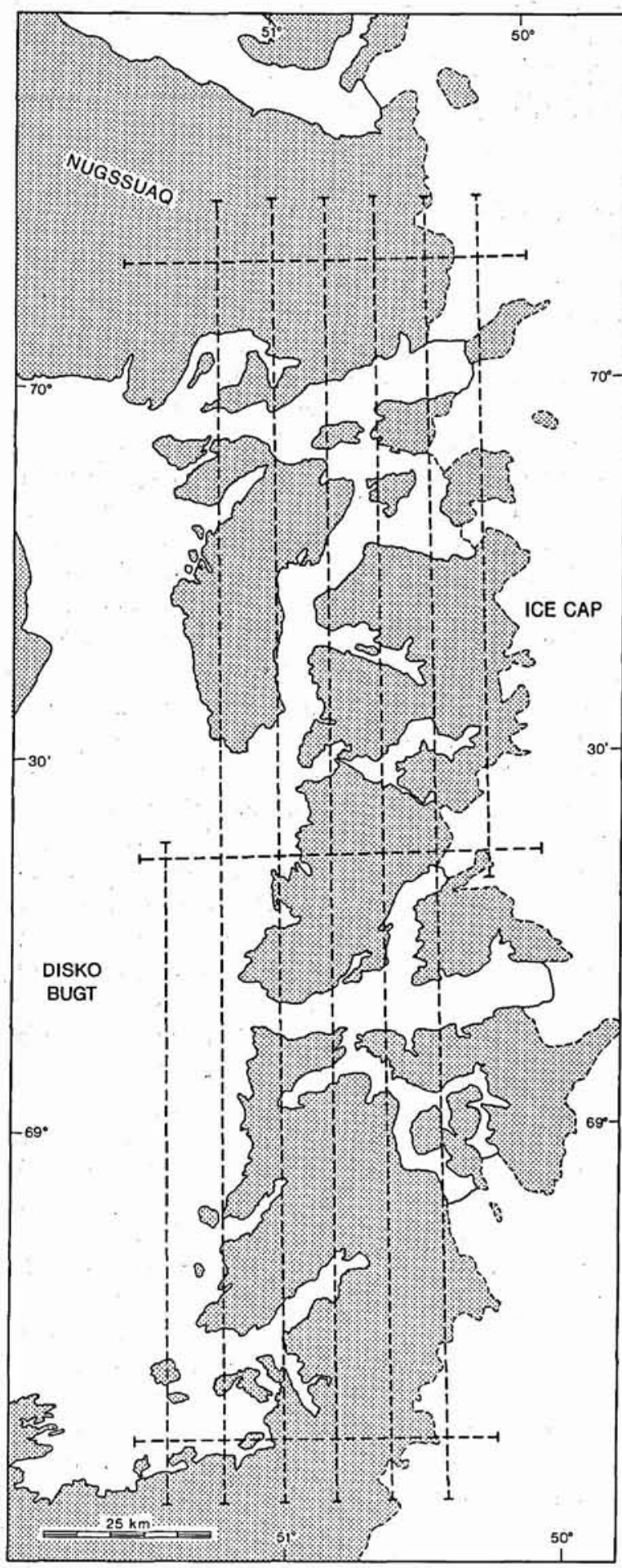

Fig. 1: Aeromagnetic lines flown in April 1987 in central West Greenland. Altogether approximately 1600 line $\mathrm{km}$ of data (total field and three gradients) were acquired.
The survey shown in fig. 1 was obtained in one $5 \mathrm{hr}$ flight out of Søndre Strømfjord and comprises seven north-south lines, spaced $10 \mathrm{~km}$ apart and three eastwest tie-lines approximately $80 \mathrm{~km}$ apart. The flight altitude was $1000 \mathrm{ft}$ above ground, sometimes levelling out at $2000 \mathrm{ft}$ over the narrower fjords and valleys. Approximately 1600 line $\mathrm{km}$ of total field data and gradients in three directions were obtained. The flight path was recorded on video for later navigation checks.

It was possible to examine the analogue recordings in the field, and these showed many well-defined anomalies, many of which could be followed from line to line. The digital data are still being processed at the National Aeronautical Establishment, before delivery to GGU where they will be compiled. It is hoped that, although the line spacing may be too wide for a faithful rendering of all the smaller scale anomalies which will then have to be interpreted on a profile basis, it will be possible to show at least the larger scale anomalies, corresponding to regional trends, on a magnetic anomaly map. In 1988 the sources of these anomalies will be checked on the ground.

Acknowledgements. The flexibility of my co-workers in the GICAS project made it possible to include the Disko Bugt survey in the tight schedule for the 1987 northern arctic operation. The costs of the operation were defrayed by GGU.

\section{References}

Knudsen, C., Appel, P. W. U., Hageskov, B. \& Skjernaa, L. 1988: Geological reconnaissance in the Precambrian basement of the Atâ area, central West Greenland. Rapp. Grønlands geol. Unders. 140 (this report).

Thorning, L., Bower, M., Hardwick, C. D. \& Hood, P. 1988: Greenland ice cap aeromagnetic survey 1987: completion of the survey over the southern end of the Greenland ice cap. Rapp. Grønlands geol. Unders. 140 (this report). 